\title{
The Pattern of Vector Control in Malaria Endemic Areas of Central Java Province
}

\author{
Wigati, R.A. ${ }^{*}$, Sidiq Setyo Nugroho ${ }^{1}$, Anggi Septia Irawan ${ }^{1}$, and Triwibowo AG ${ }^{1}$ \\ ${ }^{1}$ The Institute for Disease Vector and Reservoir Research and Development,NIHRD, Salatiga, \\ Indonesia
}

\begin{abstract}
Malaria remains a public health problem in Indonesia, therefore, a study was conducted to guarantee a reduction in malaria cases and to support an elimination program. This study aims to determine the pattern of vector control in malaria-endemic areas of Central Java Province from August to December 2016, through searching of reports and articles on malaria vector control. Malaria eradication efforts that were carried out included curative treatment and preventive action, by controlling the vector. Meanwhile, malaria vector control in Central Java Province from 2011 to 2015, includes insecticide-treated mosquito nets, larvae fish spreading, repellent use, indoor residual spraying, and larviciding. However, several obstacles to malaria vector control include, increase in the number of breeding sites, population movements from malaria endemic areas, presence of imported cases, geographic condition, attitude and behavior of people, policy differences in governance, and insufficient control budgets. Malaria is always present in Central Java Province, due to differences in vector control programme, mode of control, time, and budget. Therefore, malaria vector control policies depend on legislation, local regulation, cross-sectoral budget, support, and contribution.
\end{abstract}

Keywords: pattern, vector control, malaria endemic area

\section{Introduction}

Vector-borne diseases (malaria, dengue hemorrhagic fever, filariasis, chikungunya, and Japanase encephalitis) remain a public health problem in rural and urban areas. Meanwhile, approximately half of the world's population is at risk from malaria which is one of the main infectious diseases in Indonesia. In 2013, malaria cases reported in Indonesia were 343,527 with 80 percent from Papua, West Papua, NTT, Maluku, North Maluku while the high endemic areas were 57 [1]. Malaria is transmitted through a bite from female Anopheles mosquitoes that have been infected by Plasmodium sp [2]. Meanwhile, Indonesian Plasmodium is mostly Plasmodium falciparum and $P$. vivax or a mixture of both while P.ovale and P. malariae are found in Sulawesi, Irian Jaya, and Timor-Timur [1]. Malaria in Central Java had been known as a health problem since Dutch, Japanese, and independence era to the present development period. Also, almost all the districts had been attacked by malaria. Meanwhile, malaria cases in Central Java were recorded as follows, 0.11/1000 population in $2011,0.08 / 1000$ population in $2012,0.06 / 1000$ population $2013,0.05 / 1000$ population in 2014, and $0.06 / 1000$ population in 2015 [3,4,5,6,7].

The three main factors in the process of malaria transmission in an area include patients with or without clinical symptoms, mosquitoes or vectors, and healthy humans. Furthermore,

*Corresponding author: ajeng0102@gmail.com 
physical, chemical, biological, and socio-cultural environmental factors of local communities greatly influence the spread of malaria disease [6]. Some of these environmental risk factors include stagnant water, the distance between houses and breeding sites, the use of mosquito nets and repellents, and the habit of going out at night [7]. Therefore, the Ministry of Health has pursued various strategies, namely, fumigation of adult mosquitoes, house spraying, use of insecticide-treated bed nets, and larvasidation treatment into water reservoirs [8].

Targets and indicators to achieve national malaria elimination in 2030 include the elimination of indigenous cases of malaria transmission for 3 years respectively [9]. This process consists of 4 stages, namely, eradication, pre-elimination, elimination, and malaria control, which is performed to prevent malaria transmission [10]. Meanwhile, the elimination carried out included early discovery of appropriate treatment, strengthening migration surveillance, vector breeding sites surveillance (receptive), active case finding through Mass Blood Survey, and strengthening of referral hospitals. To achieve the national target, the activities carried out were comprehensive and integrated [11,12]. However, efforts to achieve malaria elimination have encountered many obstacles in various areas such as lack of health workers, absence of local regulations supporting networks, community involvement in the early detection systems, and adequate fundings [13]. This problem becomes complex when faced with socio-economic factors of the community, most of which are categorized as low malaria-endemic areas. Furthermore, poor environmental sanitation in an area also contributes to difficulties in eliminating malaria [14]. Meanwhile, malaria remains a health problem and the effort for eradication in an area has not focused on areas with high cases and deaths, as well as the possibility of malaria outbreaks [15]. To ensure that malaria cases remain low and eliminated, a study on the pattern of vector control in malaria-endemic areas in Central Java was conducted.

\section{Method}

The study was conducted from August to December 2016, in Kulon Progo, Magelang, Purworejo, and Pati Health Offices District through reports and articles related to malaria vector control patterns in context to malaria elimination in Central Java. Meanwhile, the data were analyzed to describe the different types of malaria vector control and several parameters studied.

\section{Results and Discussion}

\subsection{Results}

Some malaria vector control was carried out in Pati, Magelang, Purworejo, and Kulon Progo districts. The results were presented in Table 1.

Meanwhile, Kulon Progo distributed 1,050 insecticide-treated bed nets in 2015, to malaria-endemic areas, larvae fish spreading in water bodies that have the potential to be breeding sites of vector mosquitoes, and use of mosquito repellent to residents of malaria endemic areas. The efforts to control malaria in Purworejo included the distribution of 925 insecticide-treated bed nets and indoor residual spraying (IRS) to 6,800 houses in malariaendemic areas. Furthermore, Magelang distributed 375 insecticide-treated bed nets while Pati had no efforts to control malaria. 
Table 1. Malaria vector control per-districts in the year 2015

\begin{tabular}{|c|c|c|c|c|}
\hline Indicator & Pati & Magelang & Purworejo & Kulon Progo \\
\hline Total population & 1.232 .912 & 1.245 .496 & 708.038 & 408.947 \\
\hline $\begin{array}{l}\text { Risk population } \\
\text { (endemic) }\end{array}$ & 141.424 & 181.294 & 220.948 & 31.805 \\
\hline Malaria cases & 54 & 166 & 274 & 122 \\
\hline Malaria surveillance & 29 & 63 & 20 & 75 \\
\hline Migration surveillance & - & - & 4 & - \\
\hline $\begin{array}{l}\text { A number and type of } \\
\text { malaria vector control }\end{array}$ & - & $\begin{array}{l}375 \\
\text { insecticide } \\
\text {-treated } \\
\text { bed nets } \\
\text { - }\end{array}$ & $\begin{array}{l}925 \\
\text { insecticide } \\
\text {-treated } \\
\text { bed nets } \\
6.800 \\
\text { indoor } \\
\text { residual } \\
\text { spraying } \\
\text { (IRS) }\end{array}$ & $\begin{array}{l}1.050 \\
\text { insecticide- } \\
\text { treated bed } \\
\text { nets } \\
\text { larvae fish } \\
\text { spreading }\end{array}$ \\
\hline & - & - & - & repellent \\
\hline $\begin{array}{l}\text { Suspect of malaria } \\
\text { vector } \\
\text { species }\end{array}$ & $\begin{array}{l}\text { An. } \\
\text { aconitus, } \\
\text { An.barbir } \\
\text { ostris and } \\
\text { An.macula } \\
\text { tus }\end{array}$ & $\begin{array}{l}\text { An. } \\
\text { maculatus } \\
\text { and An. } \\
\text { balabacen } \\
\text { sis }\end{array}$ & $\begin{array}{l}\text { An. } \\
\text { maculatus } \\
\text { An.sundai } \\
\text { cus and } \\
\text { An. } \\
\text { balabacen } \\
\text { sis }\end{array}$ & $\begin{array}{l}\text { An. } \\
\text { maculatus } \\
\text { and An. } \\
\text { balabacensi } \\
s\end{array}$ \\
\hline
\end{tabular}

In 2014, Kulon Progo distributed 1,950 insecticide-treated bed nets to residents of malaria endemic areas with instruction to use mosquito repellent during outdoor activities and to spread larvicides onto mosquito breeding sites. Meanwhile, Purworejo distributed 950 insecticide-treated bed nets and carried out indoor residual spraying in 6,400 houses in malaria endemic areas. Furthermore, Magelang distributed 375 insecticide-treated bed nets while Pati had no efforts to control malaria (Table 2).

In 2013, Kulon Progo distributed insecticide-treated bed nets and conducted indoor residual spraying in 4,650 houses. Furthermore, Purworejo distributed 625 insecticidetreated bed nets and conducted indoor residual spraying in 4,800 houses, and spread 4,000 larvae fish. Meanwhile, Magelang distributed 375 insecticide-treated bed nets while Pati had no efforts to control malaria (Table 3). 
Malaria vector control in 2014 was presented in Table 2.

Table 2. Malaria vector control per-districts in the year 2014

\begin{tabular}{|c|c|c|c|c|}
\hline Indicator & Pati & Magelang & Purworejo & Kulon Progo \\
\hline Total population & 1.225 .594 & 1.162 .815 & 708.038 & 405.222 \\
\hline $\begin{array}{l}\text { Risk population } \\
\text { (endemic) }\end{array}$ & 141.424 & 102.985 & 220.948 & 31.694 \\
\hline Malaria cases & 118 & 6 & 240 & 87 \\
\hline Malaria surveillance & 29 & 63 & 15 & 75 \\
\hline $\begin{array}{l}\text { Migration } \\
\text { surveillance }\end{array}$ & - & - & 4 & - \\
\hline \multirow[t]{3}{*}{$\begin{array}{l}\text { A number and type } \\
\text { of malaria vector } \\
\text { control }\end{array}$} & - & $\begin{array}{l}375 \\
\text { insecticide- } \\
\text { treated bed } \\
\text { nets }\end{array}$ & $\begin{array}{l}950 \\
\text { insecticide- } \\
\text { treated bed } \\
\text { nets }\end{array}$ & $\begin{array}{l}1.950 \\
\text { insecticide- } \\
\text { treated bed } \\
\text { nets }\end{array}$ \\
\hline & - & - & $\begin{array}{l}6.400 \text { indoor } \\
\text { residual } \\
\text { spraying } \\
\text { (IRS) }\end{array}$ & Repellent \\
\hline & - & - & - & Larviciding \\
\hline $\begin{array}{l}\text { Suspect of malaria } \\
\text { vector } \\
\text { species }\end{array}$ & $\begin{array}{l}\text { An. aconitus, } \\
\text { An.barbirostr } \\
\text { is and } \\
\text { An.maculatus }\end{array}$ & $\begin{array}{l}\text { An. } \\
\text { maculatus } \\
\text { and An. } \\
\text { balabacensis }\end{array}$ & $\begin{array}{l}\text { An. } \\
\text { maculatus, } \\
\text { An.sundaicus } \\
\text { and An. } \\
\text { balabacensis }\end{array}$ & $\begin{array}{l}\text { An. maculatus } \\
\text { and An. } \\
\text { balabacensis }\end{array}$ \\
\hline
\end{tabular}

Malaria vector control in 2013 was presented in Table 3.

Table 3. Malaria vector control per-districts in the year 2013

\begin{tabular}{|c|c|c|c|c|}
\hline Indicator & Pati & Magelang & Purworejo & Kulon Progo \\
\hline Total population & 1.218 .016 & 1.162 .815 & 708.038 & 401.450 \\
\hline $\begin{array}{l}\text { Risk population } \\
\text { (endemic) }\end{array}$ & 141.424 & 355.856 & 220.948 & 31.576 \\
\hline Malaria cases & 226 & 33 & 227 & 134 \\
\hline Malaria surveillance & 29 & 63 & 20 & 75 \\
\hline $\begin{array}{l}\text { Migration } \\
\text { surveillance }\end{array}$ & - & - & 3 & - \\
\hline \multirow[t]{3}{*}{$\begin{array}{l}\text { A number and type } \\
\text { of malaria vector } \\
\text { control }\end{array}$} & - & $\begin{array}{l}375 \\
\text { insecticide- } \\
\text { treated bed } \\
\text { nets }\end{array}$ & $\begin{array}{l}625 \\
\text { insecticide- } \\
\text { treated bed } \\
\text { nets }\end{array}$ & $\begin{array}{l}4.650 \\
\text { insecticide- } \\
\text { treated bed } \\
\text { nets }\end{array}$ \\
\hline & - & - & $\begin{array}{l}4.800 \text { indoor } \\
\text { residual } \\
\text { spraying (IRS) }\end{array}$ & $\begin{array}{l}4.650 \text { indoor } \\
\text { residual } \\
\text { spraying } \\
\text { (IRS) }\end{array}$ \\
\hline & - & - & $\begin{array}{l}4.000 \text { larvae } \\
\text { fish spreading }\end{array}$ & - \\
\hline $\begin{array}{l}\text { Suspect of malaria } \\
\text { vector } \\
\text { species }\end{array}$ & $\begin{array}{l}\text { An. aconitus, } \\
\text { An.barbirostr } \\
\text { is and } \\
\text { An.maculatus }\end{array}$ & $\begin{array}{l}\text { An. } \\
\text { maculatus } \\
\text { and An. } \\
\text { balabacensis }\end{array}$ & $\begin{array}{l}\text { An. maculatus, } \\
\text { An.sundaicus } \\
\text { and An. } \\
\text { balabacensis }\end{array}$ & $\begin{array}{l}\text { An. } \\
\text { maculatus } \\
\text { and An. } \\
\text { balabacensis }\end{array}$ \\
\hline
\end{tabular}


Kulon Progo and Purworejo in 2012, implemented vector control by distributing insecticide-treated bed nets and conducting indoor residual spraying in houses. Furthermore, Magelang distributed 375 insecticide-treated bed nets while Pati District had no malaria control (Table 4).

Malaria vector control in 2012 was presented in Table 4.

Table 4. Malaria vector control per-districts in the year 2012

\begin{tabular}{|c|c|c|c|c|}
\hline Indicator & Pati & Magelang & Purworejo & Kulon Progo \\
\hline Total population & 1.207 .309 & 1.219 .371 & 708.038 & 397.639 \\
\hline $\begin{array}{l}\text { Risk population } \\
\text { (endemic) }\end{array}$ & 141.424 & 355.856 & 220.948 & 31.454 \\
\hline Malaria cases & 208 & 31 & 274 & 237 \\
\hline Malaria surveillance & 29 & 63 & 35 & 75 \\
\hline Migration surveilance & - & - & - & - \\
\hline \multirow[t]{2}{*}{$\begin{array}{l}\text { A number and type of } \\
\text { malaria vector control }\end{array}$} & - & $\begin{array}{l}375 \\
\text { insecticide- } \\
\text { treated bed } \\
\text { nets }\end{array}$ & $\begin{array}{l}\text { insecticide- } \\
\text { treated bed } \\
\text { nets }\end{array}$ & $\begin{array}{l}\text { insecticide- } \\
\text { treated bed } \\
\text { nets }\end{array}$ \\
\hline & - & - & $\begin{array}{l}\text { indoor residual } \\
\text { spraying (IRS) }\end{array}$ & $\begin{array}{l}\text { indoor } \\
\text { residual } \\
\text { spraying } \\
\text { (IRS) }\end{array}$ \\
\hline \multirow{2}{*}{$\begin{array}{l}\text { Suspect of malaria } \\
\text { vector } \\
\text { species }\end{array}$} & An.aconitus, & An. maculatus & An.maculatus, & \\
\hline & $\begin{array}{l}\text { An.barbirostr } \\
\text { is and } \\
\text { An.maculatus }\end{array}$ & $\begin{array}{l}\text { and } \quad A n . \\
\text { balabacensis }\end{array}$ & $\begin{array}{l}\text { An.sundaicus, } \\
\text { An.balabacens } \\
\text { is }\end{array}$ & $\begin{array}{l}\text { maculatus } \\
\text { and An. } \\
\text { balabacensi } \\
\text { s }\end{array}$ \\
\hline
\end{tabular}

In 2011, Kulon Progo and Purworejo distributed insecticide-treated bed nets and conducted indoor residual spraying in houses. Magelang distributed 375 insecticide-treated bed nets while Pati had no implementation on malaria control (Table 5).

One of the things that affected malaria transmission was the malaria vector, which is Anopheles sp. Therefore, it is necessary to determine the breeding sites of Anopheles sp. and the environmental conditions of the sites and the existence of these sites were a risk factor to malaria transmission $[16,17]$. Likewise, the presence of livestock is often associated with an incidence of malaria since it serves as an alternative source of blood for Anopheles sp [18]. Furthermore, cattle shed are generally used as resting places for some malaria vectors. Meanwhile, a distance of the breeding site less than $2 \mathrm{~km}$ causes a risk factor for malaria incidence because the farthest mosquito flight is within a radius of 2 to $3 \mathrm{~km}$ [19]. The mosquitoes that were suspected of being malaria vectors in Pati are An. aconitus, An. barbirostris, and An. maculatus [3]. In Purworelo, the mosquitoes that were confirmed to be malaria vectors were An.balabacensis, An. aconitus, An. maculatus [14], An.sundaicus, An.subpictus, and An.vagus [20,21,22]. Furthermore, the mosquitoes that were suspected to be vectors in Magelang include An. aconitus, An. maculatus, An. barbirostris, and An. vagus [15]. 
Malaria vector control in 2011 was presented in Table 5.

Table 5. Malaria vector control per-districts in the year 2011

\begin{tabular}{|c|c|c|c|c|}
\hline Indicator & Pati & Magelang & Purworejo & $\begin{array}{l}\text { Kulon } \\
\text { Progo }\end{array}$ \\
\hline Total population & 1.198 .529 & 1.207 .277 & 708.038 & 393.796 \\
\hline $\begin{array}{l}\text { Risk population } \\
\text { (endemic) }\end{array}$ & 141.424 & 355.856 & 220.948 & 31.326 \\
\hline Malaria cases & 198 & 15 & 333 & 157 \\
\hline Malaria surveillance & 29 & 63 & 30 & 75 \\
\hline Migration surveillance & - & - & - & - \\
\hline \multirow[t]{3}{*}{$\begin{array}{l}\text { A number and type of } \\
\text { malaria vector control }\end{array}$} & - & $\begin{array}{l}375 \\
\text { insecticide- } \\
\text { treated bed } \\
\text { nets }\end{array}$ & $\begin{array}{l}\text { insecticide- } \\
\text { treated bed } \\
\text { nets }\end{array}$ & $\begin{array}{l}\text { insecticide- } \\
\text { treated bed } \\
\text { nets }\end{array}$ \\
\hline & - & - & $\begin{array}{l}\text { indoor } \\
\text { residual } \\
\text { spraying } \\
\text { (IRS) }\end{array}$ & $\begin{array}{l}\text { indoor } \\
\text { residual } \\
\text { spraying } \\
\text { (IRS) }\end{array}$ \\
\hline & - & - & - & larviciding \\
\hline $\begin{array}{l}\text { Suspect of malaria } \\
\text { vector species }\end{array}$ & $\begin{array}{l}\text { An. aconitus, } \\
\text { An.barbirostr } \\
\text { is and } \\
\text { An.maculatus }\end{array}$ & $\begin{array}{l}\text { An. } \\
\text { maculatus } \\
\text { and An. } \\
\text { balabacensis }\end{array}$ & $\begin{array}{l}\text { An. } \\
\text { maculatus, } \\
\text { An.sundaicus } \\
\text { and An. } \\
\text { balabacensis }\end{array}$ & $\begin{array}{l}\text { An. } \\
\text { maculatus } \\
\text { and An. } \\
\text { balabacens } \\
\text { is }\end{array}$ \\
\hline
\end{tabular}

In 2011, 2012, 2013, 2014, and 2015, the malaria cases in Pati were as follows: 198, 208, 226, 118, and 54 persons respectively. Furthermore, cases were imported with no vector control from 2011 to 2015 while only disease surveillance was active.

In Purworejo, there were 227, 240, and 274 persons with malaria in 2013, 2014, and 2015 respectively. During this period, a sum of 4800, 6400, and 6800 houses were spread respectively. Meanwhile, the distribution of insecticide-treated bed nets was 625, 950, and 925. The distribution of insecticide-treated bed nets and application of indoor residual spraying (IRS) were shown in Figure 1.

Moreover, in 2011, 2012, 2013, 2014, and 2015 in Magelang, the malaria cases were as follows: $15,31,32,6$, and 166 persons respectively. Meanwhile, there was an outbreak of malaria (local transmission) in July 2015, with 56 imported cases. In Salaman I (Magelang), 75 insecticide-treated bed nets were distributed yearly to a population of 41,19 that were at risk from 2011 to 2013. 


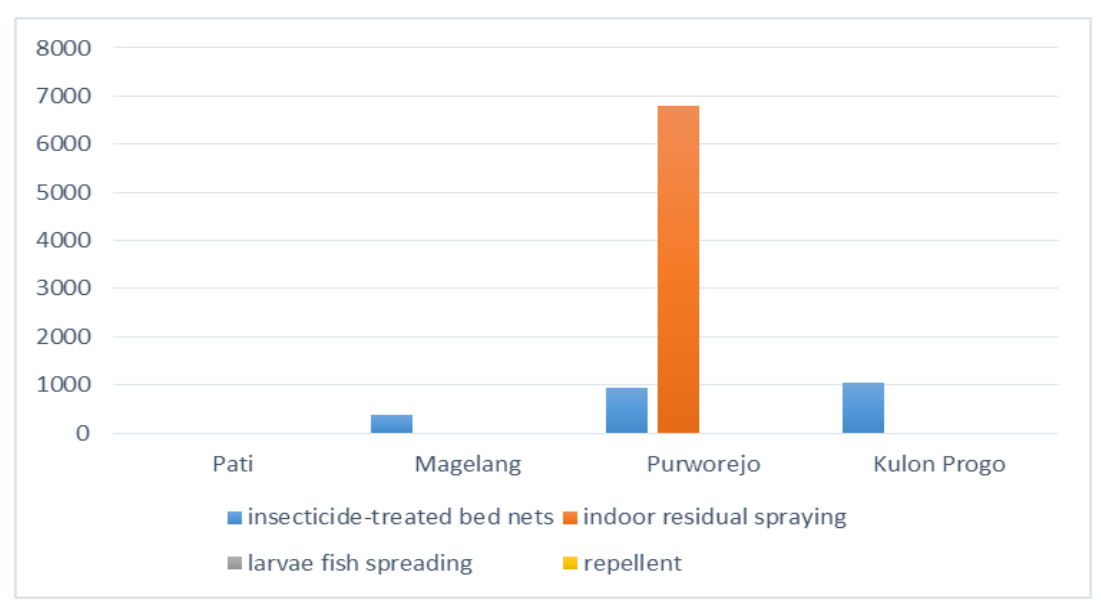

Fig. 1. Malaria control programme in Pati, Magelang, Purworejo, Kulon Progo,2015

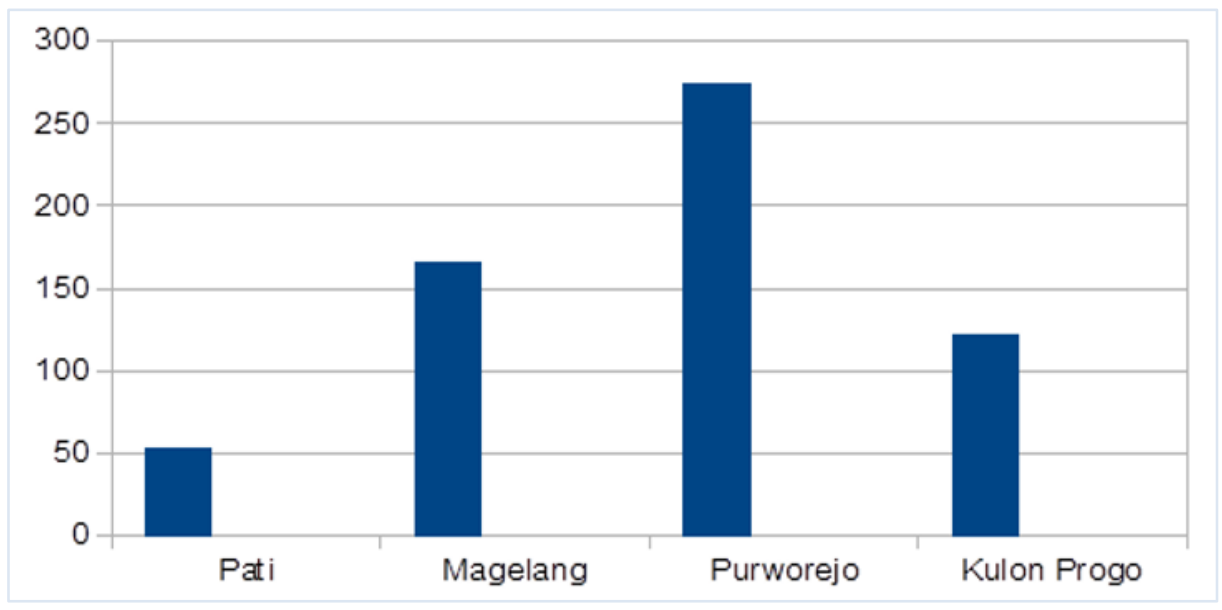

Fig. 2. Malaria cases (per-person) in Pati, Magelang, Purworejo, Kulon Progo, 2015

In Salaman II District (Magelang), the population at risk was 27,180, in Kajoran I District population at risk was 33,538, in Kajoran II District, the population at risk was 23,320, while in Borobudur District, the population at risk was 57,865. From 2011 to 2015, each district was given 75 insecticide-treated bed nets annually. Meanwhile, the number of malaria cases per person in Pati, Magelang, Purworejo, and Kulon Progo was presented in Figure 2.

Mosquitoes that were malaria vectors in Kulon Progo were An.balabacensis and An.maculatus while the cases reported per person from 2011 to 2015 are as follows; 157, 237, 134, 87, and 122. Meanwhile, the distribution pattern of malaria cases in 2015 was 38 persons at Kokap I (Health Centre) and 37 at Kokap II (Health Centre).

\subsection{Discussion}

The malaria control policies were implemented based on the regulation of the Ministry of Health, Republic of Indonesia No.374/MENKES/PER/III/2010. These policies made the vector control program an action to reduce vector population, so that its existence poses no threat for vector-borne disease transmission. One of the recommended methods was the integrated vector control using a combination of several vector controls based on the 
principles of safety and implementation effectiveness as well as the success of sustainable measures [16]. Meanwhile, several efforts have focused more on vector control before the peak of malaria transmission based on previous cases. Therefore, vector control is defined as any kind of measure directed against a vector of disease and intended to limit its ability to transmit the disease. Moreover, the current focus on malaria elimination depends on increasingly effective and affordable vector control interventions [23]. Meanwhile, malaria vector control uses one or more of the combinations stated as follows: 1) Physical and mechanical control as efforts to prevent, reduce, eliminate breeding sites, and vector populations (modification and manipulation of breeding sites such as moss cleaning, planting mangroves, drying, draining, using insecticide-treated bed nets and wire netting, using mammals as mosquitoes bait, wearing long sleeves, and trousers). 2) Controlling by using biotic agents such as predators, bacteria, viruses, fungi, and mosquito males fertilization technique. 3).Chemical control efforts such as indoor residual spraying, insecticide-treated bed nets, larviciding, fumigation, and household insecticides.

Indoor residual spraying is an effective method of vector control which involves applying a lasting insecticide to the interior walls of houses and other residential buildings. This application was aimed at killing mosquitoes that enter houses when resting on the sprayed surfaces. Meanwhile, IRS is widely used in areas of seasonal transmission, including epidemic-prone areas, and increasingly in more malaria-endemic areas. The most common insecticides used are DDT and pyrethroids. Meanwhile, this method is appropriate in epidemiological settings where vectors mainly stay indoors [24].

Insecticide-treated bed nets (ITNs) have become the most widely used form of vector control. These are more powerful than IRS and are usually less demanding logistically with an easily sustain coverage. Meanwhile, ordinary ITNs need to be treated annually year which is different from a long-lasting ITNs. These ITNs work in two ways, namely, the protection of individual users against biting and killing of some mosquitoes that try to bite. Therefore, the use of ITNs leads to a reduction in transmission at community level [25]. Deltamethrin is the most abundantly used compound, constituting approximately $60 \%$ of global usage, followed by permethrin (22\%) [26].

A guidebook on insecticide-treated bed nets published by the Ministry of Health (2010) showed that ITNs were distributed to at least $80 \%$ of the population in endemic areas where each family received two insecticide-treated bed nets. Due to the limited number of insecticide-treated bed nets, the Health Office prioritized distribution in each district to only the vulnerable groups (pregnant women, infants, and toddlers). In Central Java, 27 out of 35 districts received Malaria Elimination certificates including Magelang, and were declared malaria-free based on a decree of the Minister of Health dated April 16, 2014 [4].

Meanwhile, malaria remains the main contagious disease in Purworejo with an increase in the number of cases from 2008 to 2011 causing an outbreak. The patterns of malaria vector control in Purworejo in 2015, were the distribution of 925 insecticide-treated mosquito nets and indoor residual spraying in 680 houses. Therefore, these ITNs are proven protection to reduce malaria in endemic areas and are more protective than areas without insecticide [17]. Meanwhile, the population at risk was 220,948, and mosquitoes such as An.maculatus, An.sundaicus, and An.balabacensis were vectors [7,14]. The main obstacles to malaria control were demography and the high population of migration from Java, to malariaendemic areas. This leads to an increase in imported cases in Purworejo and transmission due to delay in treatment at the Health Centres in Kaligesing, Patuk, Sumber Biru, and Bener village which were areas with high malaria cases

The habit of not wearing a mosquito net while sleeping at night was also associated with an incidence of malaria in Kaligesing [17]. Meanwhile, Nababan and Umniyati's study (2016) [27] stated that residents with a habit of going out at night had a 3.6 times risk of contracting malaria. Moreover, control of malaria vectors in Purworejo was carried out by 
the Ministry of health after malaria transmission and the establishment of breeding sites at Menoreh hills. During the dry season, many breeding sites were water basins in rivers while during the rainy season, the sites were mountainous areas that had not been intervened by officers. The existence of these stagnant water was closely related to the incidence of malaria [23]. Previous studies by Nababan and Umniyati (2016) [27] stated that an existence of a breeding site is related to the incidence of malaria. Therefore, people living close to breeding sites have a 2.5 times risk of contracting malaria than people living far from the sites. Meanwhile, the types of water assumed to be breeding sites for Anopheles sp. mosquito larvae are puddles, ponds, ditches, paddy fields, and rivers. Furthermore, stagnant water is a place for larvae to live and breed into adult mosquitoes while environmental conditions such as agricultural, plantations, forests, paddy fields, settlements were breeding sites for Anopheles sp. [29]. The budget policy was insufficient for malaria-endemic areas and malaria vector control was carried out selectively, giving priority to people with children below five years. The use of insecticide-treated bed nets has a major impact on vectors and malaria incidences, therefore, it is recommended as effective self-protection for malaria control [19].

Kulon Progo regency is one of malaria-endemic areas in Yogyakarta and Central Java. In 2000, there was an outbreak of malaria disease in the regency with an Annual Parasite Incidence of 85.9 per 1000 population to 0.2 per mile in 2007 [30]. The pattern of malaria vector control in Kulon Progo in 2015 was distribution of 1050 insecticide-treated bed nets, larvae fish spreading, and repellent distribution while the malaria vectors were Anopheles maculatus and Anopheles balabacensis [20]. Meanwhile, the main obstacle to malaria control was the high migration of people from Java to malaria-endemic areas, which leads to importion of disease agents when returning to Kulon Progo. These imported cases cause transmission of local infection, due to delay in treating the patient with the disease at the Kokap Health Center, located in the malaria endemic area. Meanwhile, Kokap is a subdistrict in Kulon Progo Regency, Yogyakarta Province, where a sub-district is a malariaendemic area.

Malaria vector control in Kulon Progo was less than optimal because it was carried out after infection. Meanwhile, several methods carried out included insecticide residual spraying, larvaciding, insecticide-treated bed nets, distribution of repellents, and active surveillance malaria cases (active case detection) by the Health Centre to people from outside Java Island (Kalimantan and Sumatra Island). Moreover, the habit of coconut tappers when mosquitoes were active facilitates mosquitoes to have contact with tappers [22]. A previous study by Solikhah (2009) [31] showed that the differences in the distribution of malaria between men and women were influenced by work factors, where men work outside as gardeners or farmers, and migrating for work. The breeding sites of mosquitoes that were located at the Menoreh hills, during the dry season, many breeding sites were water basins in rivers while during the rainy season, the sites were in mountainous areas. Meanwhile, the malaria control policy in Kulon Progo emphasized the use of insecticide-treated bed nets and indoor residual spraying. Malaria vector control partnerships were carried out with universities, peer agencies, and others. However, in 2016, Kulon Progo Health Office had not received the malaria elimination certificate yet.

In 2015, the pattern of malaria vector control in Magelang was the distribution of insecticide-treated bed nets to 375 people, while the population at risk was 181,294 . The malaria vector mosquitoes were Anopheles maculatus and Anopheles balabacensis [4,15]. Meanwhile, the main obstacle to malaria control was demography or high population migration from Java to work areas which were malaria-endemic areas and the people returned to Magelang with a disease agent. However, there was no occurrence of local transmission because patients were immediately treated and cured at the health centers in Giripurno, Borobudur, and Magelang villages. Malaria vector control had not been carried out in the pre-adult stage (larvae) because mosquito breeding sites were widespread. 
Health centers actively conduct malaria surveillance by searching for malaria patients, especially migrants from Kalimantan and Sumatra. When there was information on malaria patients, the Environmental Health and Health Promotion Section of Magelang Health Office participated in environmental monitoring of the communities to avoid contract from imported cases. Most migrants from Sumatra and Kalimantan often come towards the mountainous areas, hence, a policy was emphasized on insecticide-treated bed nets and migration surveillance with Regulation No. 02/2012, to obtain a certificate of malaria elimination program [4]. In 2015, Magelang District revoked its malaria elimination certificate, due to a malaria outbreak from limited coverage of insecticide-treated bed nets such as the Salaman I Health Centre (Magelang) where there was an insufficient distribution of insecticide-treated bed nets. Therefore, surveillance and resistance management efforts need to be increased in malaria-endemic areas to support a successful reduction in malaria cases [24].

In 2015, the patterns of malaria vector control in Pati were only active malaria surveillance and migration, while the number of people at risk in endemic areas was 141,424 [5]. In Pati, mosquitoes that were malaria vectors include Anopheles aconitus, Anopheles barbirostris, and Anopheles maculatus. Although indoor residual spraying, larvaciding, and insecticide-treated bed nets were not carried out, the health centers had been very active in malaria surveillance, especially people that arrived from outside Java, such as Kalimantan and Sumatra, including Cluak, Tambak Kromo, and Winong health centers, which were endemic areas and have received malaria elimination certificate. These policies were emphasized to active malaria surveillance and migration.

There were some gaps in the policy of malaria vector control by the government which lead to different malaria situations. Based on the data obtained by the Health Office, a policy was needed to accelerate the elimination of malaria, including laws and regulations in support of efforts to eliminate malaria, regional regulations on exemption of the cured, ensuring availability of medical expenses for malaria patients, regional regulations on vector control relating to the environment, timely budgets, and cross-sectoral malaria control. Meanwhile, the policy for implementing a malaria control program using the guidelines of the Indonesian Ministry of Health and operation was outlined in the form of Technical Guidelines as practiced in Donggala Regency, Central Sulawesi [22].

Generally, environmental-based disease control strategies include recording and reporting of malaria cases, complete with addresses, and mapping to formulate various risk factors in an area. Malaria control is unlikely to achieve optimal results when cross-sectoral support is not involved [25]. A cross-sectoral meeting of non-governmental organizations to discuss information on the results from surveillance analysis was necessary to build partnerships on malaria prevention while evaluations were carried out annually, consistently, and periodically. Furthermore, the intervention efforts in Kulon Progo, Purworejo, and Magelang were carried out by many institutions at various levels with different types of surveillance and capacities. Therefore, developing networks for standardization since the presence of malaria is influenced by various risk factors which are cross-administrative areas, therefore, cooperation between autonomous areas was necessary.

\section{Conclusion}

The pattern of malaria vector control in Kulon Progo, Magelang, Purworejo, and Pati districts varies based on regional malaria vector control policies. Malaria vector control policies depend on laws and regulations, local regulations, budgets, and cross-sectoral support. Furthermore, malaria control was improved through regional regulations and the strengthening of existing regulations. The guidelines for vector control in each district are based on specific area coverage for effective and strengthening of malaria vector as well as 
cases. Therefore, the distribution of insecticide-treated bed nets was adjusted to the number of people at risk.

Suggestions. The suggestions that are given include the number of insecticide-treated bed nets distributed to prevent malaria transmission needs to be adjusted to the number of people at risk. Malaria surveillance of new residents from outside needs to be activated to anticipate the emergence of imported malaria cases. Furthermore, entomological surveillance needs to be carried out periodically to monitor the development of malaria vector mosquitoes. The establishment of a working group for malaria at the district level to form a network or related cross-sector cooperation, especially within a district government is also important.

Acknowledgment. The authors are grateful to the Head of The Institute for Disease Vector and Reservoir Research and Development, Salatiga for funding this study and permission to write this scientific study, and also to Mr. Hasan Boesri MS for reading and providing valuable input for an initial manuscript of this study. They are also grateful to the Head of Kulon Progo Health Office, Pati, Magelang, and Purworejo for providing local working area for this study. Furthermore, the authors are grateful to the managers of the malaria control program in each district for supporting valuable data and to Dr. Wiwik Trapsilowati for guiding in writing this study.

\section{References}

1. UF, Achmadi HH. Manajemen Penyakit Berbasis Wilayah. JManaj Pelayanan Kesehat. 2008;11 (02):72-6.

2. Arsin AA. Malaria di Indonesia. 2012. $x+199$.

3. Dinas Kesehatan Provinsi Jawa Tengah. Buku Profil Kesehatan Provinsi Jawa Tengah Tahun 2012. Jawa Tengah; 2013.

4. Dinas Kesehatan Provinsi Jawa Tengah. Profil Kesehatan Provinsi Jawa Tengah Tahun 2013. Jawa Tengah; 2014.

5. Dinas Kesehatan Kabupaten Pati. Profil Kesehatan Kabupaten Pati Tahun 2015. 2016.

6. Dinas Kesehatan Kabupaten Magelang. Profil Kesehatan Kabupaten Magelang Tahun 2015. 2016.

7. Dinas Kesehatan Kabupaten Purworejo. Profil Kesehatan Kabupaten Purworejo Tahun 2015. 2016.

8. Friaraiyatini. Pengaruh Lingkungan dan Perilaku Masyarakat terhadap Kejadian Malaria di Kabupaten Barito Selatan, Provinsi Kalimantan Tengah. Surabaya; 2005.

9. Hasyim H, Camelia A, Alam NF. Determinan kejadian malaria di wilayah endemis. Kesehat Masy Nas. 2014;8(7):291-4.

10. Ditjen P2PL. Buku Saku Menuju Eliminasi Malaria. DitJend P2PL, editor. Jakarta, Indonesia: Kemenkes RI; 2011. 30 p.

11. Roosihermiatie B, Rukmini D. Analisis Implementasi Kebijakan Eliminasi Malaria Di Provinsi Bali. Bul Penelit Sist Kesehat. 2012;15(2):143-53.

12. Pusat Data dan Informasi Kementerian Kesehatan RI. InfoDatin Malaria. Jakarta, Indonesia; 2016.

13. Lestari TRP. Pengendalian Malaria dalam Upaya Percepatan Pencapaian Target Millennium Development Goals. J Kesehat Masy Nas. 2012;07(1):22-30.

14. Kazwaini M MF. Hubungan Sebaran Habitat Perkembangbiakan Vektor Dengan Kejadian Malaria Di Daerah High Incidence Area (Hia) Kabupaten Lombok Tengah Provinsi Nusa Tenggara Barat. Bul Penelit Kesehat. 2015;43(1):23-34.

15. Balai Besar Penelitian Pengembangan Vektor dan Reservoir Penyakit S. Laporan 
Provinsi Jawa tengah Riset Khusus Vektor dan Reservoir Penyakit. Salatiga,Indonesia; 2015.

16. Munawar A. Faktor-faktor risiko kejadian malaria di Desa Sigeblog Wilayah Puskesmas Banjarmangu I Kabupaten Banjarnegara, Jawa Tengah. Universitas Diponegoro, Semarang; 2005.

17. Nurmaladewi. Hubungan Faktor Lingkungan dan Faktor Sosial Budaya dengan kejadian malaria di wilayah kerja Kabawa Kabupaten Muna Provinsi Sulawesi Tenggara. Universitas Gadjah Mada, Yogyakarta;

18. Gerrits A IS. Hubungan Faktor Lingkungan dengan Kejadian Malaria di Wilayah Kerja Puskesmas Ohiojang Kabupaten Maluku Tenggara Provinsi Maluku. Universitas Gadjah Mada, Yogyakarta;

19. Lestari EW, Sukowati S, Soekidjo WR. Vektor Malaria Di Daerah Bukit Menoreh, Purworejo, Jawa Tengah. Media Litbang Kesehat. 2007. p. 30-35.

20. Sukowati S S. Habitat perkembangbiakan dan aktifitas menggigit nyamuk Anopheles sundaicus dan Anopheles subpictus di Purworejo Jawa Tengah. J Ekol Kesehat. 2009;8 (1):915-25.

21. Widiarti, Damar TB, Barodji M. Uji Kerentanan Anopheles aconitus dan Anopheles maculatus terhadap insektisida sintetik pyrethroid di Jawa Tengah dan DIY. J Ekol Kesehat. 2005;4:227-32.

22. Widyastuti U. Inkriminasi Vektor Malaria dan Identifikasi Pakan Darah pada Nyamuk Anopheles spp. di Kecamatan Borobudur, Kabupaten Magelang. J Vektor Penyakit. 2013;5(1):18-27.

23. Organization WH. Malaria elimination: a field manual for low and moderate endemic countries. Geneva; 2007.

24. Roll Back Malaria. World Malaria Day 2010: Africa update. Progress \& Impact Series. Geneva; 2010.

25. Hill J Lines J RM. Insecticide-treated nets. Adv Parasitol. 2006;61:77-128.

26. Zain M.Jambulingam P. Global insecticide use for vector-borne disease control. 2007.

27. Resiany Nababan SRU. Faktor lingkungan dan malaria yang memengaruhi kasus malaria di daerah endemis tertinggi di Jawa Tengah: analisis sistem informasi geografis. J Community Med Public Heal. 2018;34 (no.1):11-8.

28. Shinta, S.Sukowati,Pradana A M. Beberapa aspek perilaku Anopheles maculatus Theobald di Pituruh, Kabupaten Purworejo, Jawa Tengah. Bull Penelit Kesehat. 2013;43 (3):131-41.

29. Purworejo DK. Profil Kesehatan Kabupaten Purworejo tahun 2014. Jawa Tengah; 2014.

30. Progo DKKK. Profil Kesehatan Kabupaten Kulon Progo. Yogyakarta, Indonesia; 2008.

31. Solikhah. Pola penyebaran penyakit malaria di Kecamatan Kokap Kabupaten Kulon Progo DIY Tahun 2009. Bul Penelit Sist Kesehat. 2012;15 (3) Jul:213-22.

32. Indonesia. Peraturan Menteri Kesehatan Republik Indonesia Nomor: 374/Menkes/Per/III/2010 Tentang Pengendalian Vektor. Indonesia: Kementerian Kesehatan; 2010.

33. Puspaningrum DT, Rahardjo M N. Analisis spasial pengaruh faktor lingkungan terhadap persebaran kasus malaria di Kecamatan Punggelan, Kabupaten Banjarnegara. J Kesehat Masy. 2016;4(4):882-891. 